\title{
Is the Current System of Criminal Procedure OF IRAN EFFICIENT?
}

¿ES EFICIENTE EL ACTUAL SISTEMA PROCESAL PENAL DE IRÁN?

\author{
Mehdi Fazli ${ }^{*}$ \\ Jalaleddin Ghiasi ${ }^{* *}$ \\ Mohammad Khalil Salehi***
}

\begin{abstract}
This paper is a study about the efficiency of the criminal system designed in the new Criminal Procedure Code of Iran, that came into effect on June 22, 2015. Notwithstanding the notable legislator's efforts, infrastructural and structural reforms have not been carried out. Accordingly, it is not expected to be as efficient as the previous laws due to the lack of fundamental reforms; reforms caused the improvement in "lowlevel efficiency" (saving resources in the economic sense) rather than in the "high-level" one (saving resources plus developing more justice). The analysis of the efficiency of the Code and proposal of fundamental reforms for having a high-level efficient Criminal Law in Iran are the main objectives of this paper. After an introduction (Chapters I and II), we made a historical approach of the Iranian system in this matter (Chapter III). Then, we analyze three types of efficiency (Chapter IV), attending to some infrastructural elements, some structural factors and other procedural aspects. At last, we synthetize four conclusions (Chapter V). Main conclusion is that efficiency in the system of criminal procedure would be only on low-level.
\end{abstract}

Keywords: Criminal Law, Procedural Law, Legal System, Courts System, Corruption

\footnotetext{
* Ph.D. candidate in Criminal Law and Criminology, Qom University, Faculty of Law, Qom (Iran).mrmfazli@yahoo.com

** Associate professor in Criminal Law and Criminology, Qom University, Faculty of Law, Qom (Iran). jalaleddin.ghiasi12@gmail.com

*** Assistant professor in criminal law and criminology, Qom University, Faculty of Law, Qom (Iran). mohammad.khalil.s@gmail.com
} 
Resumen: Este artículo contiene un estudio sobre la eficiencia del sistema penal diseñado en el nuevo Código de Procedimiento Penal de Irán, que entró en vigor el 22 de junio de 2015. A pesar de los notables esfuerzos del legislador, no se han llevado a cabo las reformas estructurales y estructurales necesarias. En consecuencia, no se espera que sea tan eficiente como las leyes anteriores debido a la falta de reformas fundamentales; las reformas causaron la mejora en la "eficiencia de bajo nivel" (ahorro de recursos en el sentido económico) más que en la de "alto nivel" (ahorrar recursos y desarrollar más justicia). El análisis de la eficiencia del Código y la propuesta de reformas fundamentales para contar con un Derecho Penal altamente eficiente en Irán son los principales objetivos de este documento. Después de una introducción (capítulos I y II), se da el enfoque histórico del sistema iraní en esta materia (capítulo III). Luego, se analizan tres tipos de eficiencia (en el capítulo IV), atendiendo algunos elementos, como la infraestructura, los factores estructurales y otros relacionados con el procedimiento. Finalmente, sintetizamos lo revisado en cuatro conclusiones (en el capítulo V). La principal conclusión es que la eficiencia en el sistema de procedimiento penal solo se hará a bajo nivel.

Palabras clave: derecho penal, derecho procesal, ordenamiento jurídico, sistema judiciario, corrupción

Sumario. I. Introduction. II. An introduction to the efficiency of the system of criminal procedure. II.1. Infrastructural factors. II.2. Structural factors. II.3. Procedural factors. a) Preventive measures. b) Accelerating measures. c) Terminating measures. III. Historical review of the iranian system of criminal procedure. IV. Efficency of new criminal procedure code. IV.1. Efficiency by improving infrastructural factors. a) Magistrates. b) Courts Staff. c) Police Staff. d) Corruption in Judiciary. IV.2. Efficiency through improving structural factors. a) Applying market economy thoughts to the CPC. b) Decreasing Formalism. c) Increasing specialized authorities. d) Multiple Magistrates (Judicial Panel). e) Cross-examination in Criminal Trials. f) Privatization. IV.3. Efficiency through improving procedural factors. a) Preventive Measures. b) Accelerating Measures. c) Terminative Measures. V. Conclusions. Referencias.

\section{INTRODUCTION}

The new Criminal Procedure Code of Iran (hereafter "the Code") was enacted in two parts in two different times. The first part, which includes 
general rules, detecting crimes and primary investigations, criminal courts and trial, appeal, enforcement of judgments and trial fees, was enacted in February 23, 2014. The second part, which includes criminal procedure related to armed forces crimes, electronic trial, criminal procedure related to computer crimes and criminal procedure related to corporate crimes, was enacted in September 30, 2014. The new code has been implemented since June 22, 2015 but some amendments were applied to it in June 14, a few days before its enforcement. The New code abolished the main related former laws and regulations and introduced new institutions.

Although the efficiency of the Code cannot be evaluated due to the lack of official statistics, however, this article assumes that notwithstanding legislator's struggle to reform the system of criminal procedure through the Code, no fundamental reforms have been carried out and the new Code is mainly based on the old criminal procedure laws. That is why, the Code is not expected to be highly efficient. The authors would like to examine the efficiency of the Code considering new reforms applied to it and analyse it according to infrastructural, structural and procedural (process based) factors. Such study also needs a historical review of the formation of criminal procedure law in Iran and its roots; since the Iranian legal system is a mixture of Sharia (religious)-Civil system, it is often necessary to consider which religious requirements are considered in the system of criminal procedure.

For this purpose, the issue will be discussed in three parts: the first part will provide a brief introduction about efficiency itself and efficiency in a system of criminal procedure which provides a theoretical framework for it; the second part will study the historical roots of the formation of a system of criminal procedure in Iran. By means of this, the authors will show the background of the whole structure of the system of criminal procedure of Iran; finally, the third part will examine the new code's achievements through an efficiency analysis.

\section{AN INTRODUCTION TO THE EFFICIENCY OF THE SYSTEM OF CRIMINAL PROCEDURE}

Many studies have been carried out to show that the efficiency of the justice system is a prerequisite for an investment and business friendly environment (European Commission, 2015). A stronger judiciary is associated with a more rapid growth of small firms as well as with the existence of larger firms in the economy (Dam, 2006). The system of criminal procedure as a part of the judicial system, plays an important role 
in the economic growth and development of countries. A system is a construction or collection of different elements that together produce results not reachable by the individual elements. The elements, or parts, can include people, hardware, software, facilities, policies, and documents; that is, all things required to produce system-level results. The results include systemlevel qualities, properties, characteristics, functions, behavior, and performance (NASA, 2007). Every system has an input and an output. The system should have productivity and efficiency, that is, desirable output, that is based on its input. The efficiency of a system depends on many factors; the value added by the system as a whole, contributed independently by the parts, is primarily created by the relationship among the parts; that is, how they are interconnected.

Economists divide efficiency into many types; the most important, that are related to our issue, are productive, allocative and dynamic efficiency (Barr, 1998). Productive efficiency occurs when the maximum number of goods and services (output) are produced with a given amount of input ${ }^{1}$. Allocative efficiency refers to the consumer's preferences; resources should be spent on a way to produce goods and services which are more desirable for consumer and could better satisfy his needs; so, allocation of resources to unwanted fields is referred to as a complete waste of resources, hence it is inefficient. Dynamic efficiency refers to efficiency over time; it involves the introduction of inventions, new technologies and working practices to reduce costs (Barr, 1998).

Since criminal - and also civil — procedure systems are human-made systems, a core concept of them would be efficiency. But the most important question is that what does efficiency mean in the criminal justice system? If human capital (including judges, staff, police, etc.), physical capital (including money, buildings, cars, etc.) and litigation (criminal or civil) were gathered to form units of inputs of the judicial system, what would form the efficient output of such system?

It seems that justice is the mainly expected result of every system of criminal and civil procedure; the more justice a judicial system can produce using the same or even fewer resources, the more efficient it would be (productive efficiency). Resources also should be allocated so as to maximize consumer's satisfaction by producing more justice in a form of wealth (allocative efficiency); again, there should be mechanisms to improve Dynamic efficiency by absorbing talented and virtuous staff

\footnotetext{
${ }^{1}$ For example, if a car had taken a person from A to B using 10-liter fuel, and after engine repair takes her from $\mathrm{A}$ to $\mathrm{B}$ using fewer fuel, or from $\mathrm{A}$ to $\mathrm{C}$ using same fuel, productive efficiency occurs.
} 
(including judges) and new technologies to produce more justice over the time. So, if talented and virtuous staffs are absorbed and allocation of physical and human capital resources are arrayed in the best way, so that the output of this array would have more justice and fairness than before, then the high-level or ideal efficiency of judicial system will be obtained.

However, one of the intricate problems is that justice is not measurable as a qualitative-normative concept; we cannot precisely know how much justice is produced by comparing two different months. Comparing number and time of cases dealt with in two different months also could not be a proper yardstick for measuring the amount of justice produced. Bearing in mind that every case has a winner and a loser, makes the measurability problem more complicated, because there is always a party, that is unsatisfied with the judgment; then, views of the parties in cases would not be impartial and an exact criterion for measuring the produced justice in the judicial system would not be defined. Public satisfaction is also not a suitable criterion for evaluation of justice, because people are not parties of the cases and their attitudes are mostly valueless. Complicated yardsticks should be used to evaluate the justice and order produced by the judicial system in a society.

Let's put the measurability problems of justice aside and view efficiency of the system in an economical way. Does efficiency in criminal proceedings value itself, even if it doesn't produce more justice? Does efficiency in judicial system happen, if it doesn't produce more justice than before? It seems that answer is yes; suppose that amount of justice produced by the criminal justice system in two months is the same; if we could produce the same justice saving more resources than previous month, the system would still be efficient. In this meaning of efficiency, the system of criminal procedure is not just a process for producing more justice. It also includes producing the same justice using resources efficiently. So, producing same justice using fewer resources or by preventing more resource to be wasted in one point of time than the other, would be productive efficiency again, however in low level. Although this meaning of efficiency is not free of qualitative concept, it mostly focuses on economic aspects of efficiency.

Considering both meanings of efficiency in criminal proceedings, it seems that efficiency of criminal proceedings would happen by improving triple factors: infrastructural, structural and procedural.

\section{II.1. Infrastructural factors}

Infrastructural factors refer to basic pre-proceeding factors which are fundamentals of criminal proceedings. Such factors would be external and 
internal. External factors are outside the judiciary, but may affect the criminal proceeding's efficiency. Recession, inflation, revolution, sedition, economic sanctions, inefficient banking system, inexact criminalization, good-quality regulation (OECD, 2013), etc. have indirect effect on the inefficiency of the system of criminal procedure (Dubois, Schurrer \& Velicogna, 2013), mostly due to increase in the number of lawsuits and criminal litigations. Such factors also increase the costs and impose them on judiciary. Employing more judges, more police and enforcement officials, construction of new buildings, etc. are some of such costs. Every case which enters into the judiciary entangles it; caseload in criminal authorities also makes the judges impatient, decreases the delicacy of them, as it should be spent on more important cases.

However, internal infrastructural factors relate to those factors, the management of which belongs to judiciary duties. Being favored with a mighty management in macro levels of the judiciary, benefiting from conversant, wise and virtuous judges, having educated clerks, staffs and police and enjoying desirable equipment are those internal factors which would raise the efficiency of the system of criminal procedure. Since justice is a desirable output of the judiciary, human capital plays a very important role in the productive efficiency of justice. Accordingly, ill-informed judges and uneducated staff and police, are one of the main reasons of inefficiency of the judicial system. The other main internal factor which defaces the efficiency in criminal proceedings is corruption.

\section{II.2. Structural factors}

Formalism is one of the main structural reasons of the inefficiency of the systems of civil and criminal procedures, mostly in developing countries. Formalism is associated with higher expected duration of judicial proceedings, more corruption, less consistency, less honesty, less fairness in judicial decisions, and inferior access to justice. Formalism itself has reasons and legal transplantation is one of them (Dubois, Schurrer \& Velicogna, 2013).

Formalism in criminal proceedings is more justifiable, because unlike civil proceedings which are aimed to restore balance cluttered between plaintiff and defendant, in criminal proceedings society the accused and the victim are also added; so, one of the main purposes of criminal system is to establish an equilibrium between benefits of three beneficiaries of offender, victim and society triangle.

It is anticipated that applying "market economy" approach in criminal proceedings would better ensure this equilibrium, increase the efficiency of 
the whole criminal procedure system and decrease formalism. As Posner mentions: The major function of criminal law in a capitalist society is to prevent people from bypassing the system of voluntary, compensated exchange - the "market", explicit or implicit —in situations where, because of the low transaction costs, the market, not forced exchange, is a more efficient method of allocating resources (Posner, 1985). For this reason, some scholars proposed distributive justice instead of corrective justice in the criminal system. Distributive justice, even in criminal cases, is more efficient, because it saves more resources from being wasted, as both parties are satisfied with the reconciliation and benefits of society is also protected. In fact, applying such approach to the criminal procedure system increases the productive efficiency, since it is implied that by reaching an agreement between the parties, more justice is produced and less cost is imposed on the system of criminal justice. In other words, agreementualization increases productive efficiency by producing more justice, because benefits of both parties are considered in the agreement. Therefore, it is "Pareto Efficient", because it would not make one person better off, without making another worse off. Allocative efficiency also would increase this way due to the expansion of saved resources, which will now be spent on more important cases.

Criminal proceeding has been traditionally based on forced exchange; as a result, "agreementualization" in criminal proceedings would be a very efficient approach if some age-old principles of criminal law-like retributivism - were ignored (Niyazpour, 2011).

\section{II.3. Procedural factors}

These factors relate to efficiency of the components of a system, not to the whole system. Sometimes the total structure is efficient, but some components are inefficient. The criminal procedure system constitutes of three main stages: pre-trial proceedings (including detection of crime, verification, investigations and prosecuting the offender), trial (including main trial and appeal proceedings) and enforcement of judgment. There are many differences in the mentioned stages in different countries, as those differences are based on the historical-legal system of the country (civil law, common law, etc.). Reformative measures would increase the efficiency of criminal proceedings by removing, creating or modifying the components in 
every mentioned stage ${ }^{2}$. Generally, efficiency through the modification of procedural (or process based) factors would increase by three measures:

\section{a) Preventive measures}

Preventive measures refer to those measures which judiciary could take to decrease the number of criminal litigations. In some countries, including Iran much criminal litigation brought before criminal authorities are of trivial or even civil nature. Hiring legal advocates or legal consultancy in civil or criminal cases is not mandatory and complaint fees are very low; consequently, these gaps raise the number of criminal cases, allocate the judiciary resources to inconsiderable matters and decrease the allocative efficiency. Preventive measures (like hiring legal advocates or mandatory legal consultation before litigation or increasing the litigation fees) would prevent immaterial or non-criminal cases. Although the legal consultation will act as a filter for litigations, however, it would not be affordable for many poor people. Legal aid is a suitable approach to provide legal protection to indigent people.

\section{b) Accelerating measures}

Accelerating measures refer to those measures which speed the case cycle up in the criminal process; electronization of services (OECD, 2013; Niyazpour, 2011), summary trials for petty offences etc. are examples of accelerating measures for preventing the prolongation of the criminal process.

\section{c) Terminating measures}

These measures are used to end the case cycle after issuing the judgment and let the convict get out of the system of criminal justice sooner with lower expenses. The enforcement of punishments is the last stage of the criminal procedure system, but it is the most important part. Assigning a committee for deciding on proper punishment, suspension of issuing a judgment, mitigation of punishment, probation, ordaining reward for volitional implementation of verdict etc. are some measures which could shorten the case process and let the convict leave the scene sooner, saving more resources.

\footnotetext{
${ }^{2}$ It is like a watch, the whole mechanism of which works efficiently, but lubrication of wheelworks or changing them makes it more efficient. It is self-evident that efficiency of components will raise the efficiency of the whole system.
} 


\section{HISTORICAL REVIEW OF THE IRANIAN SYSTEM OF CRIMINAL PROCEDURE}

One of the main factors of efficiency of a legal system is its historical roots. Friedrich Karl von Savigny believed that law is like a language, its rules can be formulated, but its complexity can never be fully expressed by such rules (Letwin, 2005). Transplantation of legal rules, ignores the indigenous realities which have been formed through hundreds of years coordinated by cultural, economic, political and religious structures of a country. Imported legal rules act like an inconsonant patch in a legal context; they would not be absorbed or their absorption takes many years. Moreover, transplantation of Western legal procedures to developing countries may have led to undesirably high levels of formalism (Djankov, La Porta, López-de-Silanes $\&$ Shleifer, 2002).

Criminal procedure laws of Iran -like many other laws- originated from French legal system after Constitutionalism Revolution in 1906. Many of these laws have never been fully incorporated into the criminal system of Iran. Before Constitutionalism Revolution, courts were divided into two types: canonical (religious) and conventional. The conventional courts were under the control of government, whereas canonical courts were managed by clergymen (Hakim) assigned by monarch (Zarrini \& Hojabrian, 2009). There was no independent authority for prosecution or investigation of the crime; according to Islamic rules Hakim should be Mojtahid - highest rank among clergymen who is highly qualified - the only authority for dealing with litigations, including criminal cases from the beginning till the end; there is no appeal except the one, in case of a mistake, because the system relies on Hakim (Akhoondi, 1990). Although according to Islamic (Shiite Fiqhi) rules, adjudication is just of Mojtehids rights and duties, however, sovereigns and rulers founded conventional courts by appointing their wanted judges to deal with non-religious cases, including cases related to the security of the sovereignty. After Constitutionalism Revolution such division of courts rooted from Islamic-historical realities of Iranian society lasted not very long.

Before Constitutionalism Revolution, the journeys of king Naser alDin Shah Qajar (one of the Monarchs in Qajar dynasty) to some European countries prompted him to reform the judicial system; his chancellors including Amir Kabir and Mirza Hossein Khan Sepahsalar tried to apply some reforms, but they didn't succeed (Akhoondi, 1990). In his second travel to Europe, Naser al-Din Shah asked the Austrian emperor to dispatch four military counselors to Iran. One of sent counselors, Conte de Monte Forte established a modern police and wrote a law booklet including an 
introduction on police duties and 58 articles about crimes and punishments. This booklet was the first modern criminal code of Iran (Rayejiyan Asli, 2009). After the assassination of Naser al-Din Shah, prince Mozaffar AdDin Shah became king of Iran. In his reign, murmur of protests for having "home justice" (Edalatkhaneh) began. It gradually led the country to constitutionalism revolution. Eventually, under the pressure of people, king signed the Constitution before his death in 1906.

Since the Constitution had only 51 articles, mostly related to functioning of the National and Senate parliaments and did not cover many other cases. Supplement of Constitution was prepared based on the French and Belgian Constitutions, and the new king, Mohammad Ali Shah, signed it in 1907 (Najafi \& Faqih Khani, 2002). Fundamentals of judiciary of Iran were defined by the Supplement of Constitution. It established Judiciary and divided courts into canonical and conventional; courts were firstly divided into military and appeal courts (in the center of every province) and the Supreme Court (just in capital city).

However, until 1911, no criminal procedure was carried out. In the same year, justice minister Mushiroddowleh Pirniya prepared the bill of Temporary Criminal Trials Principles Act (TCTPA) based on the French laws which was passed by Parliament in 1912 (Akhoondi, 1990; Najafi \& Faqih Khani, 2002) ${ }^{3}$. Establishment of "Parquet" (prosecution authority, including prosecutor, prosecutor assistants and interrogators) was one of the main characters of French criminal procedure system reflected in TCTPA. Police officers went under the order of parquet authorities as constables to help them in detecting crimes, investigations and service of summons. The structure of the criminal courts (appeal courts and Supreme Court) were as it was stated in supplement of the Constitution. After that, TCTPA was a subject of many amendments before the Islamic Revolution. The most important matter in the development of the system of criminal procedure after Constitutionalism Revolution was that canonical courts were gradually liquidated due to the shortage of Mojtahids, Permitted Judges (Mazoon) who were not Mojtahid (but were allowed by King) — the adjudication authority almost in all cases.

After Islamic Revolution in 1979, Islamization of laws immediately began; many laws became the subject of abolition or amendments ${ }^{4}$. Lots of

\footnotetext{
3 The bill was prepared in consultation with Français Adolphe Perny, who was the prosecutor in Paris at that time and came to Iran according to the official invitation of the Ministry of Justice. He also proposed the Establishment of Law School in Iran.

${ }^{4}$ Although many previous laws were not in explicit contradiction with Sharia rules, but the aim of legal developments after Islamic Revolution was not "contradiction", but "conformity" of rules by Islamic rules.
} 
substantive criminal laws were exposed to abolition, while procedural criminal laws, which were supposed to be less contradictive with Islamic rules, became the subject of amendments. TCTPA with some amendments ${ }^{5}$ was in effect until 1994 when the Act of Establishment of General and Revolution Courts (EGRCA) with the aim of the full Islamization of civil and criminal proceedings and direct reference of people to judges was enacted. Parquet was considered to be a non-Islamic institution due to functioning as a hinder for direct reference of people to judge and having no precedent in Islam. It was liquidated. Although EGRCA did not abolish TCTPA, its implementation, however, was similar to military courts' one. ${ }^{6}$ Criminal Procedure of General and Revolution Courts Act (hereinafter "Criminal Procedure Act") was enacted in 1999 in the event of EGRCA. Removing parquet was met with many protests of legal scholars. By removing parquet, courts which were trialed authority also became an investigative authority; although Criminal Procedure Act had ordained "Investigative magistrates" to investigate crimes under the control of judges, lots of courts, however, could not benefit from investigative magistrates due to the shortage of them; judges practically had to do investigations themselves.

The liquidation of parquet without introducing a suitable substitute for it embroiled the order established by TCTPA, so that some of the legal scholars considered it as a deathblow to the system of criminal justice of Iran (Shams, 2003); moreover, the judicial system was more accustomed to the previous system. The Criminal Procedure Act was not efficient and failed. By amending EGRCA, parquet returned to the system of criminal procedure of Iran and finally new Criminal Procedure Code was enacted in 2013. The Code abolished the whole former contradictory Acts including TCTPA and Criminal Procedure Act.

Religious problems of parquet and its inefficiency, which would be discussed below, still remain in the Code. However, the existence of parquet in the Iranian system of criminal procedure clearly shows the transplantation difficulties in the developing countries. The authors believe that if codifiers of TCTPA could define a criminal system based on religious-historical realities of Iran, such problems would never occur; even transplantation of the system of criminal procedure from common law countries would be

\footnotetext{
${ }^{5}$ Main amendments were in 1982, 1984 and 1989.

${ }^{6}$ It is still one of unanswered questions of why parquet functioning was recognized as nonIslamic just as the parquets of General and Revolution courts, while its functioning beside military courts was not.
} 
more suitable to the Iranian old system of criminal procedure due to more similarities between them.

The Code came into effect in June 2015. Statistics will soon estimate its efficiency, however, since the new code has no much difference with TCTPA, it is anticipated that no efficient outputs would happen ${ }^{7}$; this matter has been discussed below.

\section{EFFICENCY OF NEW CRIMINAL PROCEDURE CODE}

\section{IV.1. Efficiency by improving infrastructural factors}

As mentioned above, infrastructural factors include external and internal ones. External factors like economic sanctions, recession, inflation, riots, etc. are out of control of the judiciary and should be controlled by politics. Putting external factors aside, it is better to focus on major internal factors of the efficiency of the Code: magistrates, clerks and police (human capital) and corruption in the judiciary, in charge of which is judiciary itself.

\section{a) Magistrates}

Educated, experienced and virtuous judges play a key role in judiciary efficiency. However, having Bachelors in law, passing entrance exam and the several months' internship would be enough to become a judge in Iran. Employed magistrates become prosecutor assistants in parquet in a first step and should traverse some levels for becoming court judges. Many judges have a master's degree or Ph.D. in law; however, legally this is not compulsory. There are in-service trainings for judges for improvement of their work, but they seem to be insufficient ${ }^{8}$.

Appointing judges from experienced lawyers, which is carried out in some countries (like England and Wales; cfr. House of CommonsConstitutional Affairs Committee, 2004) would be a good approach to the improvement of judges' functions; however, it seems that the judiciary would not welcome to such solutions; lawyers also do not welcome such approaches because of little salary incentives. Many of the educated and experienced judges resigned in recent years because of the shortage of their salary and cumbersome duties, that is, the number of cases they handle.

\footnotetext{
${ }^{7}$ In fact, the Code has gathered TCTPA, its amendments and other related laws to it with some trivial developments.

${ }^{8}$ Some efforts have been taken place to amend the Judges Selection Conditions Act of 1982, but it will take a long time to train well-educated judges.
} 
Saving existing experienced-educated judges from getting resigned rather than employing new ones would be a priority for Iranian judiciary.

\section{b) Courts Staff}

Educated and expert clerks and staff also would increase the judiciary efficiency. Although there were struggles in recent years to increase the educational level of staff, but it seems that staff needs more special inservice trainings; besides universities should launch special university majors especially for courts staffs training.

\section{c) Police Staff}

Police staffs are constables which are acting under parquet official's supervision. In practice, many parquet officials (including interrogators and prosecutor assistants) ask the police to investigate crimes. So, the cornerstone of many criminal cases is established by police reports and investigations. The training of constables plays a crucial role in the efficiency of the system of criminal justice. There is no special "judicial police" in Iranian criminal procedure law, however, it would be necessity. Besides, it seems, because of the police help there would soon be no need for parquet at all. This matter would be discussed below.

\section{d) Corruption in Judiciary}

Corruption sacrifices the justice and undermines public trust to the judiciary. As corruption enters from one door, justice goes out from another. According to Transparency International (2016), Iran was ranked 131 among 176 countries in corruption in 2016. This shows a gradually improvement since 2013, when Iran was ranked 144 amongst 175 countries (Transparency International, 2013). There are no formal statistics about the amount and scale of corruption in Iranian judiciary to show what a big role it plays in this ranking; however, it is clear that its role is not trifle.

\section{IV.2. Efficiency through improving structural factors}

Structural factors refer to the whole structure of the criminal procedure system built by law. Below most important structural factors for the efficiency of the Code are discussed.

a) Applying market economy thoughts to the Code 
The Code has initiated a movement towards the establishment of a market economy approach and "agreementualization"; with prosecutor discretion leaving prosecution for minor offences of grade 7 and 8 (Art. 80), suspension of prosecution for minor offences of grade 6 up to 8 (Art. 81), criminal mediation in minor offences of grade 6 up to 8 (Art. 82), giving respite to accuse for acquiring victims assent in minor offences of grade 6 up to 8 (Art. 82) etc. are allowed. In all cases consent of victim and/or prosecutor is needed. However, "plea bargain" has not found a place in Criminal Procedure of Iran as in some other common law countries including the United States and England.

Applying the market economy approach to the system of criminal procedure needs a retreat in traditional principles of criminal law in Iran; one of these traditional principles is that every committed crime is supposed to be against the whole community. According to this principle every committed crime has a public aspect. Such principles today are under critique due to the emphasis of the victim's role in the criminal procedure. In addition, this approach is in harmony with Fiqhi (religious) rules.

\section{b) Decreasing Formalism}

It was expected that the Code will decrease formalism, however the Code has had not much influence in this area. Parquet, which is transplanted from French legal system and increases formalism has been affirmed in Code. One of the biggest reasons of prolongation of criminal procedure in Iran is parquet itself. In practice, most of investigations are done by police under the supervision of parquet magistrates. Footstone of criminal investigations is shaped by Police officers, while most of them have not studied law. Moreover, transfer of cases between police stations and parquet, which repeatedly takes place, increases the total time of the criminal procedure cycle. Parquet is still considered a non-Islamic institution, however, it was revived after five years elimination from the system of criminal procedure because there was no suitable substitute for it. ${ }^{9}$ Judicial Police, which some scholars had proposed, could solve the problem and increase both the productive and allocative efficiency, by removing parquet from its duties and its official transfer to the judicial police (House of Commons-Committee of Public Accounts, 2016). However, there had been no place for judicial police in the Code. Bitter experience of parquet elimination period is also a hinder.

\footnotetext{
${ }^{9}$ It should be noted that there is no parquet in county courts in small cities; duties of prosecutor in county courts would be upon county courts chief or in the case of his absence, would be upon stand-in judge.
} 
As a whole, the Code has not decreased formalism in comparison with TCTPA; it has also increased it.

\section{c) Increasing specialized authorities}

Specialization of branches of parquets and the courts is one of the measures for enhancement of the productive and dynamic efficiency.

According to the Code, "General and Revolution Parquet" is the only authority for investigation of criminal cases, except for those cases which should directly go to courts (including minor offences of degree seven and crimes against public decency) and except minor offences (of degree eight) which are within the jurisdiction of "Settlement Councils" 10 . Military courts also have their own special parquet. Head of the judiciary could establish specialized parquets like computer crimes parquet, medical and drug related crimes parquet, economic crimes parquet, etc. Although, according to Art. 25 of the Code, specialization of parquets is not mandatory and depends on the head of judiciary viewpoint, however, according to Art. 566, specialization of branches of parquets and courts is imperative.

Criminal public courts are divided into first degree and second degree courts. First degree criminal courts deal with important cases, with severe punishments whereas second degree courts deal with less important cases; Military Courts, Revolution (Enghelab) Courts and Children and Juvenile Courts are specific courts with specific jurisdictions. The appeal authority for severe sentences is a Supreme Court and appeal authority for other punishments are Appeal Courts ${ }^{11}$. Deputy of Enforcement of Criminal Judgments, which was established by Art. 484, also could have specialized units for enforcement of judgment.

Moreover, the Code has paid considerable attention to children and juveniles. Although after Islamic Revolution in 1979, Criminal Procedure Act allocated some General courts for investigating children and juvenile crimes; however, it was silent about many other details in other stages of criminal procedure. The Code has had more improvements for the protection of children and juveniles; allocation of specific constables for children and juveniles to investigate their delinquencies, allocation of specific branches of parquet, foundation of specific courts and being benefited of advisors are some of the improvements.

\footnotetext{
${ }^{10}$ Jurisdiction of Settlement Councils was limited to civil cases by 2015, but that year new Settlement Councils Act was enacted and extended its jurisdiction. Now Settlement Councils are dealing with minor offences which their punishment is degree eight fine.

${ }^{11}$ Criminal Procedure of Iran, Art. 427, has broaden appealable judgments scope.
} 
Criminal courts could deal with compensation petitions for damages caused by crime, according to victims' request; this seems to be an inefficient approach at first glance because criminal courts should deal with civil cases which have no expertise on it; however, it seems that this policy would increase the allocative and productive efficiency eventually due to preventing double hearings.

\section{d) Multiple Magistrates (Judicial Panel)}

Before the Code, trial in branches of appeal and the Supreme Court was held by multiple judges. Trial in first instance courts for serious crimes also was held by the judges' panel. The Code has continued the policy and paid attention to trial by multiple judges in serious crimes in the first instance trial. ${ }^{12}$ Serious crimes in the first instance are heard by "First Degree Criminal Courts" and "Revolution Courts", according to their jurisdictions. Utilizing a judicial panel in criminal hearings would increase productive efficiency in serious crimes, in high level meaning, however, it would decrease allocative efficiency, as it involves more judges in one trial, who could spend their time on other cases.

\section{e) Cross-examination in Criminal Trials}

A criminal procedure system of Iran is a combination of inquisitorial and adversarial considering Islamic requirements; investigations in parquet are inquisitorial, whereas hearings in court are adversarial (Akhoondi, 1990). However, according to Islamic rules, the judge can be actively involved in the investigation of the case to find out the truth. Although article 359 of the Code states that the trial should be adversarial, judge, however, himself asks questions from the parties and witnesses.

In an adversarial system an impartial person or group of people (judge or jury) should consider the litigation; advocates could represent their parties and witnesses before the court and cross-examination is carried out by advocates. However, there is no cross-examination in the Code and advocates can just ask witnesses, having judge's permission. Although cross-examination would lengthen the trial, which is against the allocative efficiency, however, it would increase productive efficiency of the criminal system by producing more justice (high-level efficiency). The legislator in

\footnotetext{
${ }^{12}$ Serious crimes are those, the punishment for which is death, life imprisonment, mutilation and grade 3 punishment or above; political and press crimes and serious intentional crimes against corporal integrity of a person are important crimes. Appeal authority for serious crimes judgments is Supreme Court.
} 
future amendments of the Code should pay more attention to crossexamination, which is carried out in common law countries. In practice, these courts mostly rely on parquet investigations and issue their judgments without consideration to defenses provided, so adversarial trial is just a superficial ceremony ${ }^{13}$.

\section{f) Privatization}

It is assumed that privatization increases productive and dynamic efficiency (Cavaliere \& Scabrosetti, 2006). Many of judicial system duties could not be privatized due to its pertinence to sovereignty. Privatization is hardly mentioned in Code. The usage of the private sector potentials for criminal mediation in minor offences (Art. 82) and servicing summons (Art. 176 of the Code) are just samples of privatization in the system of criminal procedure. Broadening the scope of criminal mediation through private institutes to include more crimes, for example children and juvenile delinquencies, in a mandatory way would increase efficiency of the system. Now it is in accordance with the market economy approach. The usage of the private sector potentials in managing prisons could also raise the efficiency of the criminal justice system; (Austin \& Coventry, 2001) however the Code does not cover this topic.

\section{IV.3. Efficiency through improving procedural factors}

Procedural improvements lubricate criminal procedure wheelworks, increase both productive and allocative efficiencies.

\section{a) Preventive Measures}

The system of criminal procedure of Iran is suffering caseload and one of main reasons for its inefficiency is a superabundant number of cases, that it has to view yearly. According to statistics, 18,417,705 criminal cases have been brought to parquet authorities during five years from 2011 until 2015 from the whole country (averagely 3,683,541 per year) ${ }^{14} ; 8,264,385$ of them have led to the indictment and were sent to the criminal courts (averagely $1,652,877$ per year). Average days for investigations in parquet were 43.4

\footnotetext{
13 According to Art. 450 of the Code appeal courts should hold trial for important convictions or convictions to imprisonment; this rule which had no precedent in previous laws gives a bigger chance to convict after just one trial.

${ }_{14}$ Detailed statistics per year show 3,192,150 cases for 2011, 3,489,631 cases for 2012, $3,750,693$ cases for 2013, 3,973,079 cases for 2014 and 4,012,152 cases for 2015. This shows a mild rise in number of criminal cases.
} 
while average days for hearing 148.2 (Research Center of Judiciary of Iran, 2017).

Although one reason for this is infrastructural factors (which was discussed above), another reason, however, is that the doors of the judiciary are open for any kind of complaint from everyone. All citizens are allowed to bring their complaints to parquet, paying not much money (about two dollars). Accordingly, low costs of criminal complaint are a big incentive. On the contrary, costs of civil action, which could be a substitute, are very high. As a result, people would rather try a criminal complaint first due to its low costs.

Moreover, hiring a lawyer or benefiting from legal advice before complaining is not mandatory. So every lay person could bring his own criminal litigation to a judiciary with not much legal knowledge and without any discretion in distinguishing civil and criminal case. Unfortunately, the Code has had no progress in the increasing costs of criminal complaints or making legal advice mandatory as preventive measures.

\section{b) Accelerating Measures}

Speeding the criminal process up has been noted in Art. 3 of the Code as a general rule. Some measures have been taken to improve the acceleration of the criminal process in the Code. Electronization of the criminal process means one of those measures: electronization of the registering of complaints, petitions and appeals, electronization of services, electronic education of magistrates, electronic connection of deputies, offices of the judiciary, police and related public authorities etc. Although part 9 of the Code is named "electronic trial", Art. 659 is about using video conference and other electronic devices for investigations (not for trial).

\section{c) Terminative Measures}

Terminative measures relate to the enforcement of judgments. There have been considerable improvements in the enforcement of punishment in Islamic Criminal Code of 2013 and the new Code; broadening of "forgivable offences" scope ${ }^{15}$ and giving the victim a bigger chance to participate in criminal procedure is one of them; according to both codes, remission by the victim can stop prosecution in parquet or enforcement of judgments in forgivable crimes. Also, according to Arts. 283 and 483 of the new Code, remission by the victim could cause suspension of prosecution in parquet or

\footnotetext{
${ }^{15}$ Forgivable offences are those offences, when the initiation or continuation of criminal process depends on victim's volition and if she forgives the offender, the case will be closed.
} 
mitigation of punishment. Convicted to imprisonment can also have a seven day leave to acquire the victim's remission. Paying fine in installments, twenty percent exemption of fine in case of voluntary payment, freedom of prisoner when enforcement of imprisonment is upon request of the victim and she has an unreasonable delay in her request, request of decreasing the probation period after six months of its implementation, freedom under the supervision of electronic systems using an electronic shackle, semi-freedom system which prisoner could have professional, educational and curative activities during his conviction etc. are notable measures in both codes for terminating punishment and faster secession of convict from criminal cycle.

Decision on the punishment belongs to the judges' duties during judgment. However, it is better, when a special committee or panel is assigned to decide on punishment or its mitigation to increase the punishment efficiency. The new Code has had no rule about a punishment panel.

\section{CONCLuSions}

At last and at least, we conclude:

1. Efficiency in the system of criminal procedure would be low-level, which means making the system work better by saving more resources, without paying attention to the amount of justice produced. This meaning of efficiency is just economical and positive.

2. However, high-level efficiency pays attention to the enhancement of justice and saves more resources. The new Code has tried to introduce improvements to a criminal procedure system of Iran; many of these improvements are procedural rather than structural or infrastructural.

3. Although procedural improvements would increase low-level efficiency, that would not be sufficient to produce the high-level one. A current system of criminal procedure of Iran is suffering infrastructural and structural flaws, and procedural improvements can not solely cure it. It was expected that the Code would obviate such flaws; however, there is not much difference between the Code and TCTPA which was enacted more than one hundred years ago. More infrastructural and structural reforms in the Code are needed in the future to lift up the high-level efficiency.

4. The improvement of processes for the selection of judges, judicial staffs and police, in infrastructural level and reforms such as applying the market economy approach, decreasing formalism, adopting crossexamination in trials, privatization, etc. in structural level would increase the high-level efficiency in a system of criminal procedure of Iran. 


\section{REFERENCES}

Akhoondi, M. (1990). Criminal Procedure Law, vol. 1. Tehran: Sazeman-e- Chap- vaEntesharat-e- Vezarat-e- Farhang- va- Ershad-e- Eslami (Organization of Publication of Ministry of Culture and Islamic Guidance).

Austin, J. \& Coventry, G. (2001). Emerging Issues on Privatized Prisons. Washington DC: United States Department of Justice (retrieved from https://www.ncjrs.gov/pdffiles1/bja/181249.pdf in 2-II-2018).

Barr, N. (1998). The Economics of the Welfare State, $3^{\text {rd }}$ ed. Stanford (California): Stanford University Press.

Cavaliere, A. \& Scabrosetti, S. (2006). Privatization and Efficiency: From Principals and Agents to Political Economy. Nota di lavoro 99.2006. Pavia (Italy): Fondazione Eni Enrico Mattei (retrieved from http://ssrn.com/abstract=914476 in 2-II-2018).

Dam, K.W. (2006). Judiciary and Economic Development. Chicago: University of Chicago, Law School (retrieved from https://www.brookings.edu/wpcontent/uploads/2016/06/200603dam.pdf in 2-II-2018).

Djankov, S., La Porta, R., López-de-Silanes, F. \& Shleifer, A. (2002). Courts: The Lex Mundi Project. National Bureau of Economic Research, Working Paper 8890 (retrieved from http://www.nber.org/papers/w8890 in 2-II-2018).

Dubois, E., Schurrer, Ch. \& Velicogna, M. (2013). The Functioning of Judicial Systems and The Situation of the Economy in the European Union Member States. Strasbourg: European Commission for the Efficiency of Justice (retrieved from http://ec.europa.eu/justice/effectivejustice/files/cepej_study_justice_scoreboard _en.pdf in 2-II-2018).

European Commission (2015). Annual Growth Survey 2016; Strengthening the Recovery and Fostering Convergence. Brussels (retrieved from http://ec.europa.eu/europe2020/pdf/2016/ags2016_annual_growth_survey.pdf in 2-II-2018)

House of Commons-Committee of Public Accounts. (2016). Efficiency in the Criminal Justice System. First Report of Session 2016-17. London: Committee of Public Accounts (retrieved from https://publications.parliament.uk/pa/cm201617/cmselect/cmpubacc/72/72.pdf in 2-II-2018).

House of Commons-Constitutional Affairs Committee (2004). Judicial Appointments and a Supreme Court (Court of Final Appeal). First Report of Session 2003-04, vol. 1, London: The Stationery Office Limited (retrieved from https://publications.parliament.uk/pa/cm200304/cmselect/cmconst/48/48.pdf in 2-II-2018).

Letwin, S.R. (2005). On the History of the Idea of Law. New York: Cambridge University Press. 
Najafi, M. \& Faqih Khani, M. (2002). History of Political Developments in Iran. Tehran: Entesharat-e-Moassese-ye-Motaleat-e-Tarikh-e-Moaser-e-Iran (Institute of Contemporary History of Iran Studies Pub).

National Aeronautics and Space Administration (NASA) (2007). NASA/SP 6105. NASA Systems Engineering Handbook, Revision 1, Washington: U.S. Government Printing Office from https://www.nasa.gov/sites/default/files/atoms/files/nasa_systems_engineering_ handbook.pdf in 2-II-2018).

Niyazpour, A. (2011). Agreementualization in Criminal Proceedings. Tehran: EntesharatMizan pub.

Organization of Economic Cooperation and Development (OECD). (2013). What makes civil justice effective? Economics Department Policy Notes, $n^{\circ} 18$. Paris: OECD (retrieved

from https://www.oecd.org/eco/growth/Civil\%20Justice\%20Policy\%20Note.pdf in 2II-2018).

Posner, A.R. (1985). An Economic Theory of the Criminal Law. Columbia Law Review, 85(6), pp. 45-52.

Rayejiyan Asli, M. (2009). Criminal Law and Criminology in Conte Law Booklet. Majalleh-Tahghighat-e-Hoghoghi (Law Researches Review), 62, Shahid Beheshti University, pp. 189-197.

Research Center of Judiciary of Iran (2017). Detailed Study of Time of Handling Cases in Judicial Units of Iran. Tehran: Markaz-e-Entesharat-e-Ghovv-e-Ghazaiyy-e (Center of Publications of Judiciary).

Shams, A. (2003). Civil Procedure Law, vol. 1, $4^{\text {th }}$ ed. Tehran: Entesharat-Mizan Pub.

Transparency International (2013). Corruption Perceptions Index (retrieved from http://www.ey.com/Publication/vwLUAssets/EY-Transparency-InternationalCorruption-Perceptions-Index-2013/\$FILE/EY-Transparency-InternationalCorruption-Perceptions-Index-2013.pdf in 2-II-2018).

Transparency International (2016). Corruption Perceptions Index (retrieved from http://www.ey.com/Publication/vwLUAssets/EY-Transparency-InternationalCorruption-Perceptions-Index-2016/\$FILE/EY-Transparency-InternationalCorruption-Perceptions-Index-2016.pdf in 2-II-2018).

Zarrini, H. \& Hojabrian, H. (2009). The Contemporary History of Judicial System of Iran and Its Developments, vol. 1. Tehran: Entesharat-e- Rouznam-e- Rasmi (Official Newspaper Pub.). 